\title{
Growth hormone regulates leptin gene expression in bovine adipose tissue: correlation with adipose IGF-1 expression
}

\author{
K L Houseknecht ${ }^{1}$, C P Portocarrero ${ }^{1}, \mathrm{~S} \mathrm{Ji}^{2}, \mathrm{R}^{2}$ Lemenager $^{1}$ and \\ M E Spurlock ${ }^{2}$ \\ ${ }^{1}$ Department of Animal Sciences, Purdue University, West Lafayette, Indiana 47907, USA \\ ${ }^{2}$ Purina Mills, St Louis, Missouri 63039, USA \\ (Requests for offprints should be addressed to K L Houseknecht, Discovery Biology, Central Research Division, BLDG 118D Room D207, Pfizer Inc., \\ Eastern Point Road, Groton, Connecticut 06340-8002, USA; Email: karen_I_houseknecht@groton.pfizer.com)
}

\begin{abstract}
Leptin, the product of the $o b$ gene, is secreted from white adipocytes and regulates food intake and whole-body energy metabolism. In rodents and humans, leptin gene expression is under complex endocrine and metabolic control, and is strongly influenced by energy balance. Growth hormone $(\mathrm{GH})$ has myriad effects on adipose tissue metabolism. The primary aim of this study was to determine the ability of $\mathrm{GH}$ to regulate leptin mRNA expression in bovine adipose tissue in vitro and in vivo. Incubation of subcutaneous adipose tissue explants for $24 \mathrm{~h}$ with $\mathrm{GH}$ alone had no effect on bovine leptin gene expression, whereas high concentrations of insulin or dexamethasone (DEX) potently stimulated bovine leptin mRNA abundance. GH, in combination with high concentrations of insulin, DEX, or both, attenuated the ability of insulin or DEX to stimulate leptin expression in vitro.
\end{abstract}

These data indicate that $\mathrm{GH}$ can indirectly regulate leptin expression in vitro by altering the adipose tissue response to insulin or DEX. We extended these studies to examine the ability of $\mathrm{GH}$ to regulate leptin expression in vivo, using young castrate male cattle treated with no hormone (control) or $\mathrm{GH}(200 \mu \mathrm{g} / \mathrm{kg}$ body weight per day) for 3 days. GH increased plasma GH and insulin concentrations, but not those of cortisol or non-esterified fatty acid (NEFA) concentrations. GH treatment increased adipose tissue leptin and IGF-1 mRNA concentrations $(n=9, \quad P>0 \cdot 001)$. In addition, leptin abundance was highly correlated with adipose tissue IGF-1 mRNA in GH-treated animals $(P>0 \cdot 001)$. The timing of $\mathrm{GH}-$ induced changes in leptin gene expression preceded measurable $\mathrm{GH}$ effects on adiposity.

Journal of Endocrinology (2000) 164, 51-57

\section{Introduction}

Leptin, the product of the $o b$ gene, has been implicated in the regulation of food intake and energy homeostasis in rodents and man. The expression of leptin in adipose tissue is highly correlated with adipose mass and adipocyte size in fully fed individuals (see reviews, Considine \& Caro 1997, Houseknecht et al. 1998). In addition, leptin gene expression in rodents and humans is under complex endocrine regulation as insulin, glucocorticoids and estrogen have been shown to stimulate leptin expression, whereas leptin concentrations in adipose tissue and serum are downregulated under conditions such as fasting, adrenergic stimulation, and cold exposure (Considine \& Caro 1997, Houseknecht et al. 1998).

Growth hormone (GH) plays an important role in the regulation of whole-body energy utilization. GH directly regulates adipocyte metabolism in domestic animals, rodents and man; GH treatment attenuates insulinstimulated lipogenesis and enhances the adipocyte response to adrenergic stimulation of lipolysis, with the net effect of partitioning nutrients away from the fat cell (see review, Etherton \& Bauman 1998). Long-term GH treatment of humans and animals significantly reduces adiposity and increases lean body mass. Furthermore, in growing animals in positive energy balance, exogenous $\mathrm{GH}$ treatment causes a reduction in food intake (Etherton \& Bauman 1998), suggesting that GH may act on central feeding centers in addition to regulating peripheral tissue metabolism.

Given the profound effects of $\mathrm{GH}$ on fat cell metabolism, one might expect that GH would regulate leptin gene expression also. The published data concerning the effect of $\mathrm{GH}$ on leptin expression are equivocal. Hardie et al. (1996) reported that incubation of isolated rat adipocytes with $\mathrm{GH}$ or insulin-like growth factor (IGF)-1 in culture had no effect on leptin synthesis or secretion, whereas others have reported that high concentrations of IGF-1 (100 nM) inhibit dexamethasone (DEX)-induced leptin expression in rat adipose tissue (Reul et al. 1997). Several studies (Considine 1997, Matsuoka et al. 1999, Miyakawa et al. 1998, Rauch et al. 1998) have examined 
the effect of long-term administration of $\mathrm{GH}$ to $\mathrm{GH}$ deficient patients; however, the results are difficult to interpret, as they are confounded by complex endocrine disorders, GH-induced changes in adiposity, or both. Therefore a primary aim of this work was to determine the effect of short-term GH treatment of healthy, growing animals on leptin gene expression in subcutaneous adipose tissue, before the occurrence of $\mathrm{GH}$-induced changes in adiposity. An additional aim was to determine the effect of GH treatment on insulin and DEX-stimulated leptin expression in vitro. We provide the first evidence that $\mathrm{GH}$ can regulate leptin gene expression in bovine adipose tissue in vivo and in vitro, and that mechanisms appear to be independent of adipose tissue mass.

\section{Materials and Methods}

\section{Animals and experimental design}

All experiments were approved by the Purdue University Committee for Animal Care and Use. Castrate male cattle (Angus, $n=12,296 \cdot 9 \pm 27 \mathrm{~kg}$ body weight) were used to determine effects of in vivo administration of $\mathrm{GH}$ on leptin expression. Animals were fed a standard complete diet for growing cattle, which was available ad libitum. The diet was formulated from corn, corn silage and protein-mineral supplement to meet National Research Council (1984) requirements for growing cattle $(12.5 \%$ crude protein, 1.28 mcal net energy gain $/ \mathrm{kg}$ dry matter). Each animal served as its own control; animals were randomly assigned to Control or $\mathrm{GH}$ treatment groups to receive daily injections, respectively, of saline or GH $(200 \mu \mathrm{g} / \mathrm{kg}$ body weight per day; Sometribov, Monsanto Corporation, St Louis, MO, USA) for 3 days, following which a subcutaneous adipose tissue sample was obtained by surgical biopsy as described elsewhere (Houseknecht et al. 1996). After a 7-day interim period for recovery from previous experimental treatment and biopsy surgery, animals received the alternate treatment and a second adipose tissue biopsy was collected. Adipose tissue samples were snap frozen and stored at $-80{ }^{\circ} \mathrm{C}$ until required for analysis for leptin and IGF-1 mRNA abundance. The short duration of $\mathrm{GH}$ treatment was chosen to alleviate the confounding effects of GH on adiposity, and we have previously shown that short-term GH treatment (2-3 days) results in significant alterations in the adipose tissue response to hormonal stimulus in cattle (Houseknecht et al. 1995, Houseknecht \& Bauman 1997). The ability of GH to induce IGF-1 mRNA expression in adipose tissue was used as a positive control, indicating a normal animal response to GH (Coleman et al. 1994).

\section{Blood sampling and analyses}

Two days before initiation of in vivo treatments, a subset of animals $(n=8)$ were fitted with indwelling jugular catheters for frequent blood sampling. Plasma samples were collected, beginning $1 \mathrm{~h}$ before the third $\mathrm{GH}$ injection (or corresponding time during the control period). Samples were collected over $24 \mathrm{~h}$ for calculation of mean daily $\mathrm{GH}$ concentrations $(-60,-30,+10,20$, $30,40,50,60,80,100,120,150,180,240,300,360,480$, $600,720,840,1000$ and $1440 \mathrm{~min}$ relative to injection). Concentrations of GH in plasma were quantified by RIA as previously described (Mollett \& Malven 1982). Plasma samples were analyzed by RIA for concentrations of insulin (Linco, St Charles, MO, USA) and cortisol (Coat-A-Count kit, Diagnostic Products, Los Angeles, CA, USA). Concentrations of free fatty acids in plasma were determined using a colorimetric kit (Wako NEFA kit, Biochemical Diagnostics, Edgewood, NY, USA). Inter- and intra-assay coefficients of variation were less than $10 \%$ for all assays.

\section{Adipose tissue culture}

Subcutaneous adipose tissue ( $\sim 15 \mathrm{~g}$ /animal) was collected from castrate male cattle $(n=11 ; 552 \cdot 4 \pm 48 \mathrm{~kg}$ body weight; all hormonal treatments were tested within each sample) immediately after exanguination. Adipose tissue explant slices $(\sim 100 \mathrm{mg})$ were prepared using a microtome after dissection to remove connective tissue. Explants were incubated ( $1 \mathrm{~g}$ adipose tissue explants/treatment) in Medium 199 (25 ml/g explants; $5 \mathrm{mM}$ glucose and acetate concentrations; Sigma, St Louis, MO, USA) supplemented with varying concentrations of hormones: basal (no hormone), bovine insulin (1, 10, $100 \mathrm{nM}$; Sigma), DEX (10, $100 \mathrm{nM}$; Sigma), GH (4, $40 \mathrm{ng} / \mathrm{ml}$; Monsanto), insulin+DEX (100 nM each), insulin $+\mathrm{GH}$ (100 nM insulin, $40 \mathrm{ng} / \mathrm{ml} \mathrm{GH})$, GH+DEX (100 nM DEX+ $40 \mathrm{ng} / \mathrm{ml} \mathrm{GH})$, insulin+DEX+GH (100 $\mathrm{nM}$ insulin and DEX, $40 \mathrm{ng} / \mathrm{ml} \mathrm{GH}$ ). The concentrations of hormones used span the range reported to be effective in regulating leptin expression in rodent and human adipose tissue (Hardie et al. 1996, Kolaczynski et al. 1996, Slieker et al. 1996). After $24 \mathrm{~h}$ in culture $\left(37^{\circ} \mathrm{C}, 5 \% \mathrm{CO}_{2}\right)$, explants were removed from the media and snap frozen until required for analysis for leptin mRNA abundance. Total RNA was extracted from adipose tissue as described elsewhere (Chomczynski \& Sacchi 1987).

\section{Ribonuclease protection analyses}

To quantify the abundance of bovine leptin mRNA in subcutaneous adipose tissue, a ribonuclease protection assay (RPA) was developed using a bovine-specific leptin riboprobe as described by Ji et al. (1998). Briefly, a 27-bp bacteriophage T7 promoter sequence was added synthetically to the $5^{\prime}$ end of antisense leptin primer (Ji et al. 1998). The resulting PCR product yields an antisense RNA when transcribed in vitro with T7 RNA polymerase. The transcription reaction was performed with $50 \mu \mathrm{Ci}$ 
$\left[\alpha-{ }^{32} \mathrm{P}\right] \mathrm{UTP}(800 \mathrm{Ci} / \mathrm{mmol})$ to generate a radiolabeled ribonucleotide probe. The in vitro transcription and RPA were accomplished using a commercially available kit (Maxiscript T7+RPA II, Ambion, Austin, TX, USA). Ten micrograms bovine adipose RNA was hybridized to the labeled probe overnight at $45^{\circ} \mathrm{C}$. For quantification purposes, each RNA was co-hybridized to an $18 \mathrm{~S}$ probe (Ambion). Single-stranded RNA was then digested with a 1:50 mixture of RNase I $(250 \mathrm{U} / \mathrm{ml})-$ RNase T1 $(10000 \mathrm{U} / \mathrm{ml})$ for $1 \mathrm{~h}$ and protected bands were separated by gel electrophoresis ( $8 \mathrm{M}$ urea, 5\% acrylamide). Band intensities were quantified by densitometry or cutting the gel and quantifying radioactivity in gel slices (d.p.m./slice; in vitro samples only), or by both techniques. Quantification of radiation in gel slices was highly correlated with densitometry values (data not shown).

Abundance of IGF-1 mRNA in subcutaneous adipose tissue samples was quantified by RPA using an IGF-1 cDNA that represents a $147 \mathrm{bp}$ portion corresponding to exon 3 as described by TaylorRoth et al. (1998; a generous gift of Dr Alan Grant, Purdue University). The antisense strand was used to synthesize a labeled riboprobe using T3 RNA polymerase (Promega, Madison, WI, USA). One milligram template was labeled using NEN $\left[\alpha_{-}{ }^{32} \mathrm{P}\right]$ $(800 \mathrm{Ci} / \mathrm{mmol})$. The probe was digested with DNase I for $30 \mathrm{~min}$ at $37^{\circ} \mathrm{C}$ and gel purified. Twenty micrograms bovine adipose RNA was hybridized to 100000 c.p.m. of probe at $45^{\circ} \mathrm{C}$ overnight. Each sample was also hybridized to an $18 \mathrm{~S}$ low activity probe to assess uniformity of RNA loading. Non-hybridized RNA was digested with a 1:50 mixture of RNase I $(250 \mathrm{U} / \mathrm{ml})-\mathrm{RNase}$ T1 $(10000 \mathrm{U} / \mathrm{ml})$ : buffer (Ambion) for $30 \mathrm{~min}$ at $37^{\circ} \mathrm{C}$. The RNA was precipitated, reconstituted in loading buffer and electrophoresed in a denaturing ( $8 \mathrm{M}$ urea, $5 \%$ acrylamide) gel. Band intensity was quantified by densitometry.

\section{Statistical analyses}

Data were analyzed by ANOVA using the STATVIEW program for Macintosh (Abicus, CA, USA). When the main effect of treatment was found to be significant $(P>0 \cdot 05)$, differences among means were determined using Fisher's protected least significant difference post hoc test. Data are presented as means \pm s.E.M.

\section{Results and Discussion}

\section{Endocrine regulation of leptin expression in vitro}

To our knowledge, there is currently no published literature describing the direct, endocrine regulation of leptin gene expression in bovine adipose tissue (in vitro). Therefore we tested the ability of varying concentrations and combinations of insulin, DEX and GH to regulate leptin expression in tissue culture (Fig. 1). Both insulin and

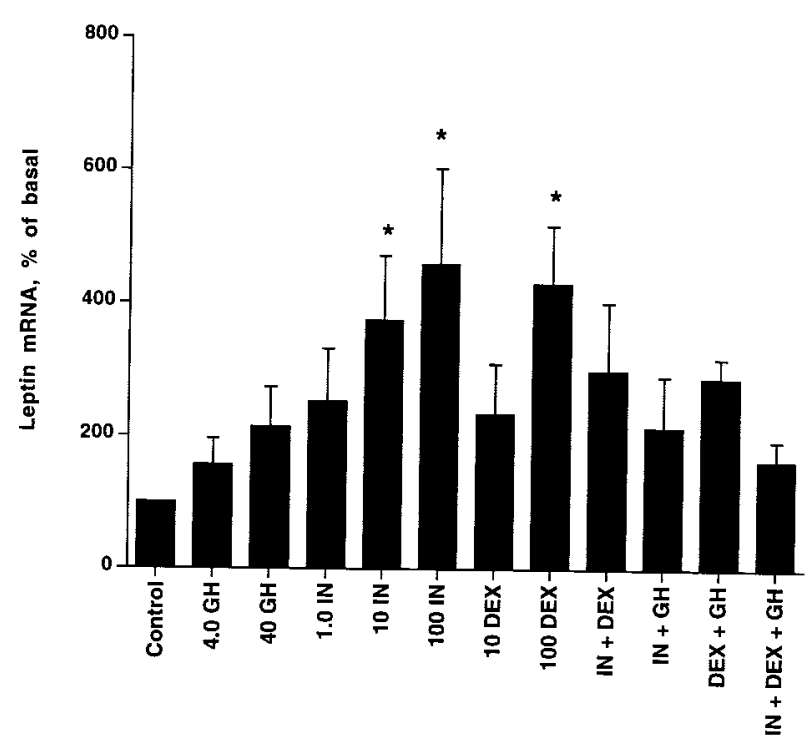

Treatment

Figure 1 Endocrine regulation of leptin mRNA abundance in bovine subcutaneous adipose tissue explant culture. Subcutaneous adipose tissue was collected at sacrifice from castrate male cattle ( $n=11 ; 552 \cdot 4 \pm 48 \mathrm{~kg}$ body weight). Explants were prepared from each animal and incubated for $24 \mathrm{hr}$ in Medium 199 in the absence (Control $=$ basal) and presence of insulin $(\mathrm{IN}), \mathrm{GH}$ or DEX, or combinations thereof: IN (1, 10, $100 \mathrm{nM})$, DEX (10, $100 \mathrm{nM}), \mathrm{GH}(4,40 \mathrm{ng} / \mathrm{ml}), \mathrm{IN}+\mathrm{DEX}$ (100 nM each), IN+GH (100 $\mathrm{nM}$ insulin, $40 \mathrm{ng} / \mathrm{ml} \mathrm{GH}), \mathrm{GH}+$ DEX $(100 \mathrm{nM} \mathrm{DEX}+40 \mathrm{ng} / \mathrm{ml}$ $\mathrm{GH}), \mathrm{IN}+\mathrm{DEX}+\mathrm{GH}$ (100 $\mathrm{nM}$ insulin and DEX, $40 \mathrm{ng} / \mathrm{ml} \mathrm{GH})$. After incubation, mRNA was prepared from explants and analyzed for leptin mRNA abundance by ribonuclease protection analysis using a bovine-specific leptin probe. Data represent means for 11 animals (tissue from each animal was subjected to all treatments). ${ }^{*} P<0.05$ compared with Control.

DEX, at high concentrations, significantly stimulated bovine leptin mRNA abundance compared with basal values $(P<0 \cdot 05)$ which is consistent with several reports in rodents and humans (Hardie et al. 1996, Kolaczynski et al. 1996, Slieker et al. 1996), but conflict with findings of others (Reul et al. 1997, Halleux et al. 1998). We observed no additive effect of insulin and DEX, similar to the findings of Considine et al. (1997), but in contrast to data reported by Hardie et al. (1996). Leptin gene expression was not significantly increased by GH treatment alone; however, GH attenuated the stimulatory effects of high concentrations of insulin, DEX, or both. Specifically, leptin mRNA abundance was significantly lower $(P<0 \cdot 03)$ for $100 \mathrm{nM}$ insulin $+40 \mathrm{ng} / \mathrm{ml} \mathrm{GH}$ compared with $100 \mathrm{nM}$ insulin. In addition, leptin mRNA abundance was lower $(P<0 \cdot 07)$ for $100 \mathrm{nM}$ insulin $+100 \mathrm{nM}$ DEX than for $100 \mathrm{nM}$ DEX. Finally, when explants were incubated with high concentrations of $\mathrm{GH}$, insulin and DEX in combination, GH completely attenuated the increase in expression observed with insulin+DEX. 
Table 1 Effect of exogenous bovine $\mathrm{GH}$ on plasma hormones and metabolites. Values are mean \pm S.E.M. for $n=9$ animals

\begin{tabular}{|c|c|c|}
\hline & Control & GH \\
\hline $\operatorname{NEFA}(\mu \mathrm{M})$ & $0 \cdot 15 \pm 0 \cdot 02$ & $0 \cdot 20 \pm 0 \cdot 05$ \\
\hline Cortisol (ng/ml) & $0 \cdot 35 \pm 0 \cdot 1$ & $0.38 \pm 0.05$ \\
\hline Insulin (nM) & $0 \cdot 2 \pm 0 \cdot 05$ & $0.5 \pm 0 \cdot 15^{\star}$ \\
\hline
\end{tabular}

Effect of exogenous $G H$ administration on plasma $G H$ and IGF-1 $m R N A$ abundance

Next, we chose to expand our findings to examine the effect of bovine GH administration in vivo on leptin gene expression. Daily administration of $\mathrm{GH}$ significantly $(P<0 \cdot 001)$ increased average daily circulating $\mathrm{GH}$ concentrations compared with the control period $(n=9$; control: $2 \cdot 1 \pm 0 \cdot 6 \mathrm{ng} / \mathrm{ml}, \mathrm{GH}: 62 \cdot 4 \pm 6 \mathrm{ng} / \mathrm{ml})$. Induction of IGF-1 mRNA in adipose tissue in response to $\mathrm{GH}$ treatment was used as a positive control, to ensure that animals were eliciting a known biological response to $\mathrm{GH}$ treatment. This is especially important, given the short duration of GH treatment, in which no observable change in growth rate or food intake could be quantified. Three of the 12 animals used in this experiment did not acclimatize to the metabolism stalls in which they were housed, as indicated by aggressive behavior during blood sampling, reduced food intake $(9 \cdot 8 \pm 1.2 \mathrm{~kg}$ dry matter intake/day compared with $13 \cdot 1 \pm 0.7 \mathrm{~kg} /$ day for fully acclimatized animals) and lack of body weight gain over the course of the study (both control and GH treatment periods). Consistent with being in zero or negative energy balance, these animals exhibited no increase in IGF-1 expression in response to $\mathrm{GH}$ despite significantly increased plasma $\mathrm{GH}$ concentrations $(n=3 ; 69 \cdot 1 \pm 15 \cdot 0 \mathrm{ng} / \mathrm{ml})$. Therefore, data from this small subset of animals were removed from the means presented.

In the remaining animals $(n=9), \mathrm{GH}$ treatment caused a significant $(P<0 \cdot 001), 4 \cdot 8$-fold, increase in IGF-1 mRNA abundance in adipose tissue. This is consistent with results previously reported in the pig (Coleman et al. 1994) and with increased circulating IGF-1 reported in GH-treated animals (see review, Etherton \& Bauman 1998).

\section{Effect of exogenous GH on plasma hormones and metabolites}

Exogenous GH treatment caused a twofold increase in plasma insulin concentrations, with no change in plasma cortisol concentrations (Table 1). These data are consistent with previous reports on the effect of $\mathrm{GH}$ treatment of cattle (Dunshea et al. 1995, Bauman \& Vernon 1996). Furthermore, there was no effect of exogenous GH on plasma non-esterified fatty acid concentrations (Table 1 ).
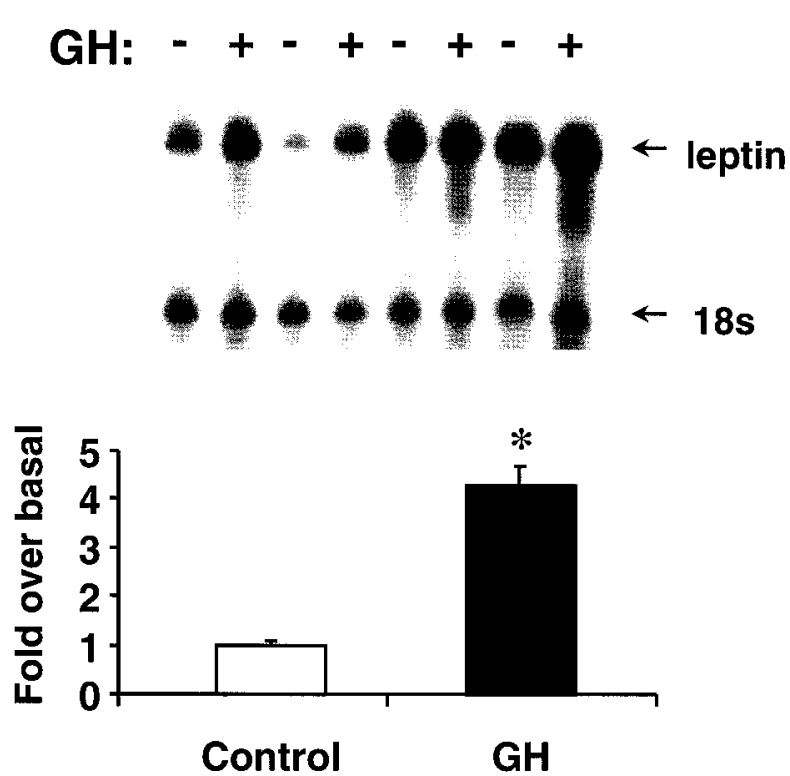

Figure 2 Effect of short-term (3-day) exogenous bovine GH treatment on leptin gene expression in subcutaneous adipose tissue. Castrate male cattle were treated with daily injections of saline (Control) and bovine $\mathrm{GH}(200 \mu \mathrm{g} / \mathrm{kg}$ body weight per day; Sometribov, Monsanto Corporation) for 3 days (switchback design). Approximately $18 \mathrm{~h}$ after the third injection, a subcutaneous adipose tissue biopsy was collected for analysis of leptin gene expression. Total mRNA was extracted from tissues and analyzed for leptin mRNA abundance by ribonuclease protection analysis using a bovine-specific leptin riboprobe. Upper panel: a representative experiment; lower panel: data from all animals $(n=9)$. Treatment of animals for 3 days with bovine $\mathrm{GH}$ significantly increased leptin mRNA abundance compared with the control period $\left({ }^{*} P<0 \cdot 001\right)$.

Effect of GH on leptin mRNA abundance in subcutaneous adipose tissue

GH treatment significantly $(P<0 \cdot 001)$ increased leptin mRNA abundance in animals exhibiting a positive IGF-1 response (Fig. 2). Interestingly, the three animals in zero/negative energy balance that did not respond to $\mathrm{GH}$ with increased IGF-1 exhibited a significant downregulation of leptin expression in response to $\mathrm{GH}$ treatment ( $\sim 50 \%$ reduction; data not shown). Accordingly, concentrations of leptin mRNA were highly correlated with adipose tissue IGF-1 mRNA concentrations during both positive and zero/negative energy balance $(n=12$, $r=0 \cdot 81, P<0 \cdot 001$; Fig. 3).

\section{General Discussion}

We have provided evidence that GH can regulate leptin gene expression independently of $\mathrm{GH}$-induced effects on adiposity. We tested this hypothesis using both in vitro and in vivo approaches, and provide the first evidence of $\mathrm{GH}$ 


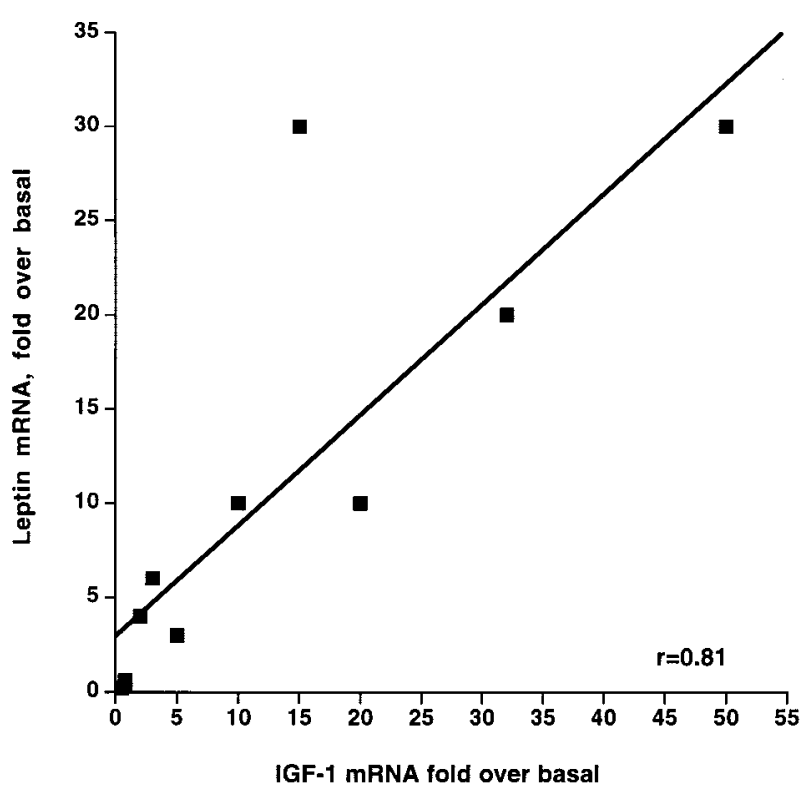

Figure 3 Correlation between expression of IGF-1 and leptin in subcutaneous adipose tissue. Castrate male cattle $(n=12)$ were treated with daily injections of saline (Control) and bovine $\mathrm{GH}$ $(200 \mu \mathrm{g} / \mathrm{kg}$ body weight per day; Sometribov, Monsanto Corporation) for 3 days (switchback design). Approximately $18 \mathrm{~h}$ after the third injection, a subcutaneous adipose tissue biopsy was collected for analysis of leptin and IGF-1 gene expression by ribonuclease protection analysis. Leptin expression was highly correlated $(r=0 \cdot 81, P<0 \cdot 001)$ with IGF-1 expression in adipose tissue.

regulation of leptin gene expression in cattle. It has been well documented in studies with rodents and humans that insulin and glucocorticoids are potent stimulators of leptin gene expression (see reviews, Considine \& Caro 1997, Houseknecht et al. 1998). Recently, Isozaki et al. (1999) have reported that $\mathrm{GH}$ administration (7 days) to obese, hyperleptinemic Zucker fatty rats reduced leptin mRNA expression in visceral, but not subcutaneous, adipose tissue. However, there is a paucity of data that indicate that $\mathrm{GH}$ regulates leptin expression in adipose tissue of normal animals, independent of $\mathrm{GH}$-induced changes in adiposity.

Work by Hardie et al. (1996) showed that, when isolated rat adipocytes were incubated with either GH or IGF-1 alone, there was no effect on leptin secretion into the incubation medium, in contrast to increased secretion in response to insulin or glucocorticoids. We extended the work of Hardie et al. (1996) to include incubation of bovine adipose tissue explants with insulin, DEX, and $\mathrm{GH}$ alone and in combination, and confirmed that GH alone had no effect on leptin gene expression in bovine subcutaneous adipose tissue. However, when incubated in combination, GH attenuated the insulin- or DEXinduced stimulation of leptin gene expression. These in vitro data are consistent with work of others (see reviews,
Bauman \& Vernon 1993, Etherton \& Bauman 1998) that has shown that one effect of exogenous GH treatment is to inhibit insulin-mediated events in the adipocyte, such as stimulation of lipogenesis, inhibition of lipolysis and activation of adipogenic genes.

To examine further the role of $\mathrm{GH}$ in regulating leptin expression in adipose tissue, and to delineate endocrine mechanisms underlying leptin gene expression in cattle, we extended our work to include short-term exogenous $\mathrm{GH}$ treatment in vivo. Much of the literature in which the effects of exogenous $\mathrm{GH}$ of human subjects on leptin gene expression has been examined is difficult to interpret, because of the confounding effects of GH deficiency or chronic disease on leptin expression, in addition to GHinduced changes in adiposity. We hoped to minimize such confounding effects in our study by choosing a short duration of treatment ( 3 days) and treating normal animals that had no GH-related pathology. We were fairly confident that this short window of treatment should be sufficient to reveal the effects (if any) of GH on adipose tissue leptin expression, as we and others (Houseknecht et al. 1995, Kerber et al. 1998) have shown that GHinduced changes in adipocyte biology, such as an increased response to $\beta$-adrenergic agents and a reduced response to insulin, are in place within 15-24 h of treatment. Indeed, after 3 days of GH treatment, there was a significant up-regulation of adipose tissue IGF-1 mRNA, consistent with an appropriate biological response to GH (Coleman et al. 1994). Furthermore, the GH-induced up-regulation of IGF-1 mRNA in adipose tissue was accompanied by a significant increase in leptin mRNA abundance.

The differing effects of $\mathrm{GH}$ on bovine leptin gene expression we report in the in vitro versus in vivo studies highlights the complexity of the in vivo system. The simplified in vitro system provides evidence that GH can modulate leptin expression, presumably via alteration in tissue response to hormones such as insulin and DEX. In vivo, the hormonal and nutritional milieu are more complex and, as $\mathrm{GH}$ inhibited leptin gene expression in vivo, it is tempting to speculate that $\mathrm{GH}$ effects are modulated by other hormonal and nutritional factors. The fact that others (Hardie et al. 1996, Isozaki et al. 1999) have shown no direct effect of IGF-1 on leptin gene expression supports the notion that GH effects on leptin expression are not mediated by IGF-1. However, others (Boni-Schnetzler et al. 1999, Reul et al. 1997) have reported a negative effect of IGF-1 on leptin gene expression, thus more research is needed to clarify if the effects of $\mathrm{GH}$ on leptin gene expression are mediated via effects on IGF-1.

The high correlation between IGF-1 expression and leptin expression in adipose tissue was quite striking. Coleman et al. (1994) previously reported that GH potently stimulates IGF-1 gene expression in adipose tissue of pigs; to our knowledge, our data are the first such report in cattle. Furthermore, it was interesting that, in the three 
animals that were in zero/negative energy balance during both the control and GH treatments, there was a significant down-regulation in leptin expression and a downregulation or no change in IGF-1 expression in response to GH (Fig. 3). Thus the strong correlation between leptin and IGF-1 mRNA abundance holds for all animals tested, regardless of response to GH. Similarly, Fine et al. (1998) have recently reported a high correlation between adipose tissue leptin and IGF-1 expression in fed and fasted rats. However, although leptin and IGF-1 mRNA expression are correlated in adipose tissue of rodents and cattle, these data do not prove that leptin gene expression is regulated by IGF-1.

The reciprocal effects of $\mathrm{GH}$ to stimulate or inhibit leptin gene expression, depending upon the animal's energy balance, are consistent with the feeding behavior commonly observed with GH treatment. When growing animals in positive energy balance are treated with exogenous $\mathrm{GH}$, there is a characteristic decrease in food intake (see review, Etherton \& Bauman 1998). As experimentally induced increases in leptin have been shown to inhibit food intake in rodents (see reviews, Considine \& Caro 1997, Houseknecht et al. 1998), it is tempting to speculate that a $\mathrm{GH}$-induced increase in leptin expression could provide such a signal to reduce food intake in cattle. Conversely, when GH is administered to animals in negative energy balance, there is typically an increase in food intake to support the increased metabolic demand incurred by GH treatment (Etherton \& Bauman 1998). Again, on the basis of rodent data, a GH-induced decrease in leptin expression could provide a profound stimulus to eat, under these conditions.

Finally, several groups have reported that leptin regulates GH secretion in rodents (Carro et al. 1997, 1998, 1999, Tannenbaum et al. 1998, Vuagnat et al. 1998), sheep (Roh et al. 1998) and pigs (Barb et al. 1998), and that exogenous leptin is able to prevent the fasting-induced decrease in GH secretion, but not IGF-1 secretion, in fasting rats (LaPaglia et al. 1998). Our data coupled with data on the regulation of $\mathrm{GH}$ secretion by leptin, highlight the important link between leptin and the GH-IGF-1 axis in communicating the nutritional and metabolic status of the animal, and have important implications in the regulation of animal growth and development.

\section{Acknowledgements}

The authors thank R Griebenow and L Houghton for assistance with animal handling and care, and $\mathrm{C}$ Funkhouser, M Leininger, J Siegal-Willot and E Wesby for assistance in sample collection. We also thank Monsanto for the donation of bovine growth hormone (Sometribov), A Grant, Purdue University, for donation of the IGF-1 cDNA, and P Malven and S Haglof for the plasma GH determination. This research was supported by Purdue University Agriculture Research Programs (K L H). Data were presented in part at the Eighth International Congress on Obesity, Paris, France, September 1998 .

\section{References}

Barb CR, Yan X, Azain MJ, Kraeling RR, Rampacek GB \& Ramsay TG 1998 Recombinant porcine leptin reduces feed intake and stimulates growth hormone secretion in swine. Domestic Animal Endocrinology 15 77-86.

Bauman DE \& Vernon RG 1993 Effects of exogenous bovine somatotropin on lactation. Annual Review of Nutrition 13 437-461.

Boni-Schnetzler M, Hauri C \& Zaph J 1999 Leptin is suppressed during infusion of recombinant human insulin-like growth factor I (rhIGFI-) in normal rats. Diabetologia 42 160-166.

Carro E, Senaris R, Considine RV, Casanueva FF \& Dieguez C 1997 Regulation of in vivo growth hormone secretion by leptin. Endocrinology 138 2203-2206.

Carro E, Seoane LM, Senaris R, Considine RV, Casanueva FF \& Dieguez C 1998 Interaction between leptin and neuropeptide Y on in vivo growth hormone secretion. Neuroendocrinology 68 187-191.

Carro E, Senaris RM, Seoane LM, Frohman LA, Arimura A, Casanueva FF \& Dieguez C 1999 Role of growth hormone (GH)-releasing hormone and somatostatin on leptin-induced GH secretion. Neuroendocrinology 69 3-10.

Chomczynski P \& Sacchi N 1987 Single-step method of RNA isolation by acid guanidinium thiocyanate-phenol-chloroform extraction. Analytical Biochemistry 162 156-159.

Coleman ME, Russell L \& Etherton TD 1994 Porcine somatotropin (pST) increases IGF-I mRNA abundance in liver and subcutaneous adipose tissue but not in skeletal muscle of growing pigs. Journal of Animal Science 72 918-924.

Considine RV 1997 Weight regulation, leptin and growth hormone. Hormone Research 48 116-121.

Considine RV \& Caro JF 1997 Leptin and the regulation of body weight. International Journal of Biochemistry and Cell Biology 29 $1255-1272$.

Considine RV, Nyce MR, Kolaczynski JW, Zhang PL, Ohannesian JP, Moore JH, Fox JW \& Caro JF 1997 Dexamethasone stimulates leptin release from human adipocytes - unexpected inhibition by insulin. Journal of Cellular Biochemistry 65 254-258.

Dunshea FR, Boisclair YR, Bauman DE \& Bell AW 1995 Effects of bovine somatotropin and insulin on whole-body and hindlimb glucose metabolism in growing steers. Journal of Animal Science $\mathbf{7 3}$ 2263-2271.

Etherton TD \& Bauman DE 1998 Biology of somatotropin in growth and lactation of domestic animals. Physiological Reviews $\mathbf{7 8}$ 745-761.

Fine J, Villafuerte BC, Bai Y, Zhao W, Tagra K, Fleming S, Hauman D \& DiGirolamo M 1998 Effects of chronic food restriction on circulating levels and adipose regional gene expression of leptin and IGF-1. International Journal of Obesity 22 S164.

Halleux CM, Servais I, Reul BA, Detry R \& Brichard SM 1998 Multihormonal control of ob gene expression and leptin secretion from cultured human visceral adipose tissue - increased responsiveness to glucocorticoids in obesity. Journal of Clinical Endocrinology and Metabolism 83 902-910.

Hardie LJ, Guilhot N \& Trayhurn P 1996 Regulation of leptin production in cultured mature white adipocytes. Hormone and Metabolic Research 28 685-689.

Houseknecht KL \& Bauman DE 1997 Regulation of lipolysis by somatotropin: functional alteration of adrenergic and adenosine signaling in bovine adipose tissue. Journal of Endocrinology 152 $465-475$. 
Houseknecht KL, Dwyer DA, Lanna DP \& Bauman DE 1995 Effect of somatotropin on adipose tissue metabolism: ontogeny of the enhanced response to adrenergic challenge in the lactating cow. Domestic Animal Endocrinology 12 105-113.

Houseknecht KL, Bauman DE, Vernon RG, Byatt JC \& Collier RJ 1996 Insulin-like growth factors-I and II, somatotropin, prolactin and placental lactogen are not acute effectors of lipolysis in ruminants. Domestic Animal Endocrinology 13 239-249.

Houseknecht KL, Baile CA, Matteri RL \& Spurlock ME 1998 The biology of leptin - a review. Journal of Animal Science $\mathbf{7 6}$ $1405-1420$.

Isozaki O, Tsushima T, Miyakawa M, Nozoe Y, Demura H \& Seki H 1999 Growth hormone directly inhibits leptin gene expression in visceral fat tissue in fatty Zucker rats. Journal of Endocrinology 161 511-516.

Ji SQ, Willis GM, Scott RR \& Spurlock ME 1998 Partial cloning and expression of the bovine leptin gene. Animal Biotechnology 9 1-14.

Kerber JA, Wray Cahen D, Boyd RD \& Bauman DE 1998 Decreased glucose repose to insulin is maximal within $24 \mathrm{~h}$ of somatotropin injection in growing pigs. Domestic Animal Endocrinology 15 267-270.

Kolaczynski JW, Nyce MR, Considine RV, Boden G, Nolan JJ, Henry R, Mudaliar SR, Olefsky J \& Caro JF 1996 Acute and chronic effect of insulin on leptin production in humans - studies in vivo and in vitro. Diabetes 45 699-701.

LaPaglia N, Steiner J, Kirsteins L, Emanuele M \& Emanuele N 1998 Leptin alters the response of the growth hormone releasing factor growth hormone insulin-like growth factor-I axis to fasting. Journal of Endocrinology 159 79-83.

Matsuoka H, Fors H, Bosaeus I, Rosberg S, Albertsson-Wikland K \& Bjarnason R 1999 Changes in body composition and leptin levels during growth hormone treatment in short children with various GH secretory capacities. European Journal of Endocrinology 140 $35-42$.

Miyakawa M, Tsushima T, Murakami H, Isozaki O, Demura H \& Tanaka T 1998 Effect of growth hormone (GH) on serum concentrations of leptin - study in patients with acromegaly and GH deficiency. Journal of Clinical Endocrinology and Metabolism $\mathbf{8 3}$ 3476-3479.
Mollett TA \& Malven PV 1982 Chronological profiles of prolactin and growth hormone in lactating cows. Journal of Dairy Science $\mathbf{6 5}$ 211-216.

National Research Council 1984 Nutrient Requirements of Beef Cattle. Washington, DC: National Academy Press.

Rauch F, Westermann FA, Englaro P, Blum WF \& Schonau E 1998 Serum leptin is suppressed by growth hormone therapy in growth hormone-deficient children. Hormone Research 50 18-21.

Reul BA, Ongemba LN, Pottier AM, Henquin JC \& Brichard SM 1997 Insulin and insulin-like growth factor 1 antagonize the stimulation of $o b$ gene expression by dexamethasone in cultured rat adipose tissue. Biochemical Journal 342 605-610.

Roh SG, Clarke IJ, Xu RW, Goding JW, Loneragan K \& Chen C 1998 The in vitro effect of leptin on basal and growth hormonereleasing hormone secretion from the ovine pituitary gland. Neuroendocrinology 68 361-364.

Slieker LJ, Sloop KW, Surface PL, Kriauciunas A, Laquier F, Manetta J, Buevalleskey J \& Stephens TW 1996 Regulation of expression of ob mRNA and protein by glucocorticoids and cAMP. Journal of Biological Chemistry 271 5301-5304.

Tannenbaum GS, Gurd W \& Lapointe M 1998 Leptin is a potent stimulator of spontaneous pulsatile growth hormone $(\mathrm{GH})$ secretion and the GN response to GH-releasing hormone. Endocrinology 139 3871-3875.

TaylorRoth JL, Malven PV, Gerrard DE, Mills SE \& Grant AL 1998 Independent effects of food intake and insulin status on insulin-like growth factor-I in young pigs. Comparative Biochemistry and Physiology 120 357-363.

Vuagnat BAM, Pierroz DD, Lalaoui M, Englaro P, Pralong FP, Blum WF \& Aubert ML 1998 Evidence for a leptin-neuropeptide Y axis for the regulation of growth hormone secretion in the rat. Neuroendocrinology 67 291-300.

Received 14 April 1999

Revised manuscript received 6 August 1999

Accepted 18 August 1999 